\title{
ANALISIS POTENSI PAJAK REKLAME TERHADAP PENDAPATAN ASLI DAERAH DI KOTA MAKASSAR
}

\author{
Muhaimin $^{1}$ Faidul Adzim² Firmansyah $^{3}$ \\ Universitas Muhammadiyah Makassar \\ e-mail : imsanmuha@gmail.com
}

\begin{abstract}
Research aims to know the large number of potential tax billboards in the city of Makassar, billboards tax collection, contributions to the contribution of local income tax, the effectiveness of the poll, as well as increased contribution efforts Income tax on the original revenue of Makassar city. This research uses data collection techniques in the form of literature review, interviews, and documentation. The results showed that the potential of the billboards owned by the city of Makassar for the year 2014 to 2016 increase annually, but there is still a potential that has not been shaken optimally. The Billboards tax collection system in place of the government of DISPENDA Makassar is the official assessment. For the year 20122014 the contribution of billboards tax on local tax and local revenue was increased annually, but there was a decline in local tax and local revenue in 2015 and 2016.
\end{abstract}

Keywords: potential analysis, billboards, indigenous revenue

\begin{abstract}
Abstrak
Penelitian ini bertujuan untuk mengetahui besar jumlah Potensi Pajak Reklame di Kota Makassar, sistem pemungutan pajak reklame, kontribusi pajak reklame terhadap pendapatan asli daerah, efektifitas pemungutan, serta upaya peningkatan kontribusi pajak reklame terhadap Pendapatan Asli Daerah Kota Makassar. Penelitian ini menggunakan teknik pengumpulan data berupa tinjauan kepustakaan, wawancara, dan dokumentasi. Hasil penelitian menunjukka bahwa potensi pajak reklame yang dimiliki Kota Makassar untuk tahun 2014 sampai 2016 mengalami peningkatan tiap tahunnya, namun masih terdapat potensi yang belum tergali secara optimal. Sistem pemungutan pajak reklame yang diberlakukan pihak DISPENDA Kota Makassar yaitu sitem official assessment. Untuk tahun 20122014 Kontribusi pajak reklame terhadap Pajak Daerah dan Pendapatan Asli Daerah mengalami peningkatan tiap tahunnya, namun terjadi penurunan kontribusi terhadap Pajak Daerah dan Pendapatan Asli Daerah pada tahun 2015 dan 2016. Pemungutan pajak reklame yang dilakukan oleh pihak Dinas Pendapatan Daerah Kota Makassar telah efektif karena mampu melebihi target yang telah ditetapkan.
\end{abstract}

Kata Kunci: Analisis Potensi, Pajak Reklame, Pendapatan Asli Daerah 


\section{PENDAHULUAN}

Otonomi daerah di Indonesia memiliki fungsi dalam mengusahakan kesejahteraan dan kemakmuran rakyatnya. Untuk dapat mewujudkan hal tersebut, segala potensi dan sumber daya yang ada harus dialokasikan secara efektif dan efisien secara terus-menerus sehingga pembangunan nasional dapat terwujud. Hal ini terlihat pada pemerintah pusat melalui otonomi kepada pemerintah daerah untuk mengelolah daerahnya sendiri. Lahirnya media baik cetak dan elektronik, dijadikan sebagai modal besar untuk para pengguna sektor perdagangan, salah satu yang paling diminati adalah pemasaran lewat media reklame. Media reklame dianggap sebagai alternatif pemasaran yang menguntungkan dan sangat efektif, reklame dianggap mampu menarik calon konsumen karena reklame bisa diakses oleh semua pihak.

Hal ini menjadikan reklame sebagai salah satu yang harus diperhatikan oleh pemerintah, baik dalam hal pemberian aturan dan tarif pemasangan reklame yang diatur oleh undangundang maupun peraturan daerah. Pajak Reklame dapat memberikan kontribusi tersendiri terhadap penerimaan pendapatan asli daerah (PAD), sehingga pemerintah diharap dapat mengoptimalkan objek pajak ini guna menambah pendapatan asli daerah (PAD) yang akan di gunakan untuk membiayai kegiatan rutin pemerintahan dan membiayai pembangunan. Sebagai sumber penerimaan yang dapat memberikan kontribusi tersendiri terhadap pendapatan asli daerah dikota Makassar, pemerintah diharap mampu mengoptimalkan potensi yang dimiliki pajak reklame.

Namun kondisi yang terjadi di Kota Makassar tidak sesuai dengan yang di harapkan. Hal tersebut termuat dalam perkataan Ketua Asosiasi Pengusaha Reklame Indonesia (ASPRI) yang mengatakan bahwa masih banyak pelanggaran pemasangan reklame yang harus ditertibkan, begitu juga dengan potensi penerimaan pajak baru harus lebih dioptimalkan (Bisnis Indonesia, 2012:10). Hal tersebut menyiratkan bahwa potensi pajak reklame dikota Makassar cukup besar namun aturan yang diterapkan oleh pemerintah daerah dalam hal pengelolaan yang dikelolah Dinas Pendapatan Kota Makassar masih belum optimal.

\section{TINJUAN PUSTAKA}

\section{Pajak}

Definisi pajak menurut Bohari (2012) Pajak adalah iuran pada negara (yang dapat dipaksakan) yang terutang oleh yang wajib membayarnya menurut peraturan-peraturan dengan tidak dapat prestasi kembali, yang langsung dapat ditunjuk, dan yang gunanya adalah untuk membiayai pengeluaranpengeluaran umum berhubungan dengan tugas pemerintah.

\section{Pajak Daerah}

Definisi pajak daerah menurut UndangUndang Nomor 28 Tahun 2009 Tentang Pajak Daerah dan Retribusi Daerah Pasal 1 Angka 10 adalah Pajak Daerah, yang selanjutnya disebut Pajak, adalah kontribusi wajib kepada Daerah yang terutang oleh orang pribadi atau badan yang bersifat memaksa berdasarkan UndangUndang, dengan tidak mendapatkan imbalan secara langsung dan digunakan untuk keperluan Daerah bagi sebesar-besarnya kemakmuran rakyat. Dasar Hukum pemungutan Pajak Daerah dan Retribusi Daerah adalah Undangundang No.28 Tahun 2009 tentang Pajak Daerah dan Retribusi Daerah

\section{Pajak Reklame}

Pengertian Pajak Reklame dan Reklame berdasarkan Peraturan Daerah Kota Makassar Nomor 3 Tahun 2010 Tentang Pajak Daerah Bab I Pasal 1 angka 16 dan 17 adalah Pajak Reklame adalah pajak atas penyelenggaraan reklame. Menurut Peraturan Daerah Kota Makassar Nomor 3 Tahun 2010 Tentang Pajak Daerah Bab VI Bagian Kedua Pasal 29, tarif pajak reklame ditetapkan sebesar 25\% (dua puluh lima persen). Dasar pemungutan Pajak Reklame pada suatu kabupaten atau kota (Siahaan, 2013) adalah sebagai berikut.

a. Undang-Undang Nomor 28 Tahun 2009 tentang Pajak Daerah dan Retribusi Daerah.

b. Undang-Undang Nomor 34 Tahun 2000 yang merupakan perubahan atas Undang-Undang Nomor 18 Tahun 1987 tentang Pajak Daerah dan Retribusi Daerah.

c. Peraturan Pemerintah Nomor 65 Tahun 2001 tentang Pajak Daerah.

d. Peraturan daerah kabupaten/kota yang mengatur tentang Pajak Reklame.

e. Keputusan bupati/walikota yang mengatur tentang Pajak Reklame sebagai aturan 
pelaksanaan peraturan daerah tentang Pajak Reklame pada kabupaten/kota dimaksud.

\section{Potensi}

Definisi potensi menurut Kamus Bahasa Indonesia (2008) Potensi adalah daya kekuatan; kemapuan; kesanggupan. Dari pengertian di atas dapat disimpulkan bahwa potensi pajak reklame yang dimaksud adalah segala kempuan yang dimiliki pajak reklame untuk menjadi sumber penerimaan bagi suatu daerah, sehingga pajak reklame dapat pula dikatakan sebagai target penerimaan pajak reklame yang telah ditetapkan oleh Dinas Pendapatan Daerah Kota Makassar berdasarkan hasil perhitungan yang akan dicapai dalam suatu periode.

Adapun rumus perhitungan potensi pajak raklame (Prakosa, 2005) yaitu:

Potensi Pajak Reklame (PPrk) $=\mathrm{R}$ x S x D x Pr

Keterangan:

PPrk $=$ Potensi Pajak Reklame

$\mathrm{R}=$ Jumlah Reklame

$\mathrm{S}=$ Ukuran Reklame/ Luas Reklame

$\mathrm{D}=$ Jumlah har

$\mathrm{Pr}=$ Tarif Reklame

\section{Pendekatan Penelitian}

Pendekatan yang digunakan dalam penelitian ini adalah pendekatan kuantitatif dengan ilmiah yaitu berfikit untuk memecahkan masalah secara sistematis, empiris, dan terkontrol yang dengan angka-angka. Objek Penelitian ini adalah Penelitian ini bertempat di Kantor Dinas Pendapatan Daerah (DISPENDA) Kota Makassar di Jl. Urip Sumiharjo, Maccini, Kec. Makassar, Kota Makassar, Sulawesi Selatan Adapun jenis data yang digunakan dalam penelitian ini adalah data kualitatif dan kuantitatof, sedangkan Sumber data yang diperoleh dalam penelitian ini adalah sumber sekunder.

\section{Metode Analisis Data}

Penelitian ini menggunakan metode deskriptif Kualitatif dan deskriptif Kuantitatif. Deskriptif Kualitatif yaitu metode yang berusaha menampilkan kondisi yang didapatkan peneliti pada saat melakukan penelitian. Penelitian deskriptif Kuantitatif ini bertujuan untuk menggambarkan Potensi yang dimiliki Pajak Reklame sebagai salah satu sumber Pendapatan Asli Daerah (PAD) di Kota Makassar.

\section{METODE}

\section{HASIL DAN PEMBAHASAN}

Tabel 1. Kontribusi Pajak Reklame Terhadap Penerimaan Pajak Daerah dan Pendapatan Asli Daerah Di Kota Makassar Tahun 2012 - 2015

\begin{tabular}{|c|c|c|c|c|c|}
\hline \multirow[b]{2}{*}{ Tahun } & \multicolumn{2}{|c|}{ Realisasi Penerimaan } & \multicolumn{2}{|c|}{ Kontribusi } & \multirow[b]{2}{*}{$\begin{array}{l}\text { Pendapatan } \\
\text { Asli Daerah }\end{array}$} \\
\hline & Pajak Reklame (Rp) & Pajak Daerah (Rp) & $\begin{array}{l}\text { Pendapatan Asli } \\
\text { Daerah (Rp) }\end{array}$ & $\begin{array}{c}\text { Pajak } \\
\text { Daerah } \\
(\%)\end{array}$ & \\
\hline 2012 & $4.843 .715 .225,-$ & 98.318.693.736,- & 154.911.936.959,-- & $4,93 \%$ & $3,12 \%$ \\
\hline 2013 & $7.093 .462 .210,-$ & 115.223.338.974,- & 170.698.725.814,- & $6,16 \%$ & $4,15 \%$ \\
\hline 2014 & 11.336.841.164,-- & 133.551.818.678,- & 210.136.331.088,- & $8,49 \%$ & $5,40 \%$ \\
\hline 2015 & 16.936.119.593.- & $270.547 .821 .316,-$ & $351.692 .552 .588,-$ & $6,26 \%$ & $4,81 \%$ \\
\hline
\end{tabular}

Sumber: Diolah sendiri

Dapat dilihat dari table 4.5 di atas pada tahun 2012 kontribusi pajak reklame terhadap pajak daerah mencapi $4,93 \%$ dan terhadap pendapatan asli daerah mencapai 3,12\%, kemudian pada Tahun 2013 mengalami peningkatan yaitu sebesar $6,16 \%$ pada pajak daerah dan $4,15 \%$ pada pendapatan asli daerah, pada tahun 2014 kontribusi pajak reklame kembali mengalami peningkatan yaitu sebesar $8,49 \%$ pada pajak daerah dan $5,40 \%$ pada pendapatan asli daerah, persentase kontribusi pajak reklame mengalami penurunan pada tahun 2015 yaitu sebesar $6,26 \%$ pada pajak daerah dan $4,81 \%$ terhadap pendapatan asli daerah.

\section{Analisis Efektifitas Pajak Reklame Berdasarkan Realisasi Dan Target}




\begin{tabular}{ccccc}
\hline \hline Tahun & $\begin{array}{c}\text { Realisasi Pajak } \\
\text { Reklame }\end{array}$ & $\begin{array}{c}\text { Target Pajak } \\
\text { Reklame }\end{array}$ & Efektifitas & Keterangan \\
\hline 2012 & Rp. 4.843.715.225,- & Rp. 6.588.006.480,- & $73,4 \%$ & Kurang Efektif \\
\hline 2013 & Rp. 7.093.462.210,- & Rp.10.079.284.950,- & $70,4 \%$ & Kurang Efektif \\
\hline 2014 & Rp.11.336.841.164,- & Rp.10.386.827.000,- & $109,1 \%$ & Efektif \\
\hline 2015 & Rp.16.936.119.593,- & Rp.16.000.079.000,- & $105,8 \%$ & Efektif \\
\hline
\end{tabular}

Sumber: Diolah Sendiri

Dari tabel di atas dapat dilihat seberapa besar tingkat efektifitas pemungutan pajak reklame dari potensi yang ada.

a. Realisasi penerimaan pajak reklame tahun 2014 sebesar Rp.11.336.841.164,- dan potensi yang dimiliki sebesar Rp. 11.779.651.000,. Adapun tingkat efektifitas pemungutan pajak reklame dari potensi yang dimiliki sebesar 96,24\%, sehingga peneliti dapat menyimpulkan bahwa pemungutan pajak reklame yang dilakukan oleh DISPENDA Kota Makassar cukup efektif, namun masih terdapat $3,76 \%$ potensi yang belum tergali secara optimal. b. Realisasi penerimaan pajak reklame tahun 2015 sebesar Rp.16.936.119.593,- dan potensi yang dimiliki sebesar Rp. 18.539.417.500,-. Adapun tingkat efektifitas pemungutan pajak reklame dari potensi yang dimiliki sebesar 91,35\%, sehingga peneliti dapat menyimpulkan bahwa pemungutan pajak reklame yang dilakukan oleh DISPENDA Kota Makassar cukup efektif, namun masih terdapat $8,65 \%$ potensi yang belum tergali secara optimal.

\section{Perbandingan Realisasi, Target, dan Potensi Pajak Reklame}

Tabel 3 . Perbandingan Realisasi, Target, dan Potensi Pajak Reklame Kota Makassar Tahun 2014 2015

\begin{tabular}{cccc}
\hline Tahun & Realisasi Pajak Reklame & Target Pajak Reklame & Potensi Pajak Reklame \\
\hline 2014 & Rp.11.336.841.164,- & Rp.10.386.827.000,- & Rp.11.779.651.000,- \\
\hline 2015 & Rp.16.936.119.593,- & Rp.16.000.079.000,- & Rp.18.539.417.500,- \\
\hline
\end{tabular}

Sumber: Diolah Sendiri

Dari tabel di atas dapat dilihat perbandingan realisasi, target, dan potensi pajak reklame Kota Makassar.

a. Tahun 2014 realisasi pajak reklame sebesar Rp. 11.336.841.164,-. Adapun target yang ditetapkan sebesar Rp. 10.386.827.000,-, sedangkan potensinya mampu mencapai sebesar Rp. 11.779.651.000,-.

b. Tahun 2015 realisasi pajak reklame meningkat sebesar Rp.16.936.119.593,-. Adapun target yang ditetapkan sebesar Rp.16.000.079.000,-, sedangkan potensinya mampu mencapai sebesar Rp.18.539.417.500,-.

Peneliti mengambil kesimpulan bahwa meskipun target pajak reklame yang ditetapkan oleh DISPENDA Kota Makassar tahun 2014 2015 dapat tercapai melalui penerimaan yang mampu melebihi target yang ditetapkan, namun potensi pajak reklame jauh lebih besar dari jumlah penerimaan pajak reklame. Hal ini menggambarkan masih terdapat potensi pajak reklame belum tergali secara optimal. padahal apabila potensi ini dapat dimaksimalkan maka akan menambah kontribusi terhadap PAD Kota Makassar.

\section{KESIMPILAN DAN SARAN}

\section{Kesimpulan}

Adapun kesimpulan dari fokus permasalahaan dalam penelitian ini mengenai potensi pajak reklame akan dijabarkan sebagai berikut.

a. Potensi pajak reklame yang dimiliki Kota Makassar Tahun 2014 sebesar 11.779.651.000,pada tahun berikutnya yaitu tahun 2015 sebesar 18.539.417.500.

b. Kontribusi pajak reklame tahun 2012 mencapi $4,93 \%$ terhadap pajak daerah dan 3,12\% terhadap pendapatan asli daerah, kemudian pada Tahun 2013 mengalami peningkatan yaitu sebesar $6,16 \%$ pada pajak daerah dan $4,15 \%$ pada pendapatan asli daerah, pada tahun 2014 kontribusi pajak reklame kembali mengalami peningkatan yaitu sebesar $8,49 \%$ pada pajak daerah dan $5,40 \%$ pada pendapatan asli daerah, persentase kontribusi pajak reklame mengalami penurunan pada tahun 2015 yaitu sebesar $6,26 \%$ pada pajak daerah dan $4,81 \%$ terhadap pendapatan asli daerah,.

c. Tingkat efektifitas pemungutan pajak reklame terhadap target pajak reklame yang dilakukan 
oleh DISPENDA Kota Makassar tahun 2012 kurang efektif karena hanya mampu mencapai $73,4 \%$. Tahun 2013 pemungutan yang dilakukan masih kurang efektif karena hanya mampu mencapai 70,4\%. Tahun 2014 pemungutan yang dilakukan DISPENDA Kota Makassar telah efektif karena mampu mencapai $109,1 \%$. Tahun 2015 pemungutan pajak efektif karena mampu mencapai $105,8 \%$.

\section{Saran}

Berdasarkan hasil penelitian yang didapat, maka penulis memberikan saran-saran sebagai berikut:

a. Perlu melakukan pendataan secara rutin terhadap objek pajak reklame yang sudah ada sehingga dapat diketahui potensi yang sebenarnya melalui data objek pajak tersebut. Selain itu proses penetapan target harusnya memperhatikan potensi yang sebenarnya sehingga DISPENDA Kota Makassar akan terpacu untuk mencapai target tersebut dan dapat meningkatkan penerimaan pajak reklame.

b. Seharusnya potensi yang belum tergali secara optimal dapat dimanfaatkan oleh pihak DISPENDA khususnya Bidang III Pajak Reklame guna memaksimalkan pendapatan pajak reklame.

c. Perlu melakukan sosialisasi secara rutin terhadap wajib pajak guna meningkatkan kesadaran wajib pajak terhadap kewajibannya dalam hal ketaatan pembayaran pajak tepat waktu dan tepat jumlah. DISPENDA juga diharap mampu memberikan sanksi tegas terhadap wajib pajak yang kurang taat dalam melaksanakan kewajibannya.

d. Perlu mengadakan pelatihan rutin terhadap staf DISPENDA Kota Makassar sendiri khususnya Bidang III Reklame guna meningkatkan kualitas Sumber Daya Manusia para staf tersebut. Memperhatikan segala sarana dan prasarana khusunya perbaikan sistem komputerisasi sehingga tidak menghambat jalannya segala aktifitas di bidang III reklame serta melakukan perekrutan staf bila dianggap perlu.

e. Diharapkan pada penelitian berikutnya yang akan membahas topik yang sama, agar memperluas ruang lingkup penelitiannya.

\section{REFERENSI}

Adi, N, B. 2012. Kontribusi Pajak Reklame Dalam Meningkatkan Pendapatan Asli Daerah (PAD) Di Kabupaten Kediri (Studi Kasus Pada Dinas Pendapatan, Pengelolaan Keuangan dan Aset Daerah Kabupaten Kediri)

Bisnis Indonesia, 21 April, 2012. Potensi Pajak Reklame Besar, hlm. 10.

Bohari. 2012. Pengantar Ilmu Hukum Pajak. Jakarta: PT. Raja Grafindo Persada.

Danfar. 2009. Education, Business, Communication, and Information.

Fidel. 2010. Cara Mudah \& praktis Memahami Masalah-Masalah Perpajakan: Mulai Dari Konsep Dasar Sampai Aplikasi. Jakarta: Murai Kencana.

Himpunan Peraturan Daerah Kota Makassar Nomor 3 Tahun 2010 Tentang Pajak Daerah. 2010. Makassar: Dinas Pendapatan Kota Makassar.

Kamus Bahasa Indonesia. 2008. Jakarta: Pusat Bahasa Departemen Pendidikan Nasional.

Keputusan Walikota Makassar Nomor: 500/423/KEP/IV/2013 Tentang Penetapan Perhitungan Nilai Sewa Reklame Kota Makassar. 2013. Makassar: Dinas Pendapatan Kota Makassar.

Laki, M.A. 2011. Analisis Proses Penerapan Perhitungan, dan Pelaporan Pajak Reklame pada Kantor Dinas Pendapatan Daerah (DISPENDA) Kota Makassar. Skripsi tidak diterbitkan. Makassar. Fakultas Ekonomi dan Bisnis Universitas Hasanuddin Makassar.

Mahmudi. 2010. Manajemen Kinerja Sektor Publik Edisi Kedua. Yogyakarta: UPP STIM YKPN.

Mardiasmo. 2009. Akuntansi Sektor Publik. Yogyakarta: Andi.

Mardiasmo. 2013. Perpajakan: Edisi Revisi. Yogyakarta: Andi.

Pedoman Penulisan Skripsi. 2012. Makassar: Fakultas Ekonomi dan Bisnis Universitas Hasanudin. Peraturan Walikota Makassar Nomor 40 Tahun 2009 Tentang Uraian Tugas Jabatan Struktural Dinas Pendapatan Kota Makassar. 2009.

Prakosa. 2005. Pajak dan Retribusi Daerah Edisi Revisi. Yogyakarta: UII Press.

Sekaran, U. 2009. Metodologi Penelitian Untuk Bisnis Edisi 4 Buku 1. Jakarta: Salemba Empat. 
Siahaan, M.P. 2013. Pajak Daerah dan Retibusi Daerah Edisi Revisi. Jakarta:PT. Raja Grafindo Persada.

Suwarno, A, E. dan Suhartiningsih. 2008. Efektifitas Evaluasi Potensi Pajak Daerah sebagai Sumber Pendapatan Asli Daerah. Jurnal Akuntansi dan Keuangan, (online), Vol.7, No. 2

Triantoro, A. 2010. Efektifitas Pemungutan Pajak Reklame dan Kontribusinya Terhadap Penerimaan Pajak Daerah di Kota Bandung. Jurnal Fokus Ekonomi, (online), Vol.5, No.1.

Undang-Undang Republik Indonesia Nomor 28 Tahun 2007 tentang Perubahan Ketiga atas Undang-undang Nomor 6 Tahun 1983 tentang Ketentuan Umum dan Tata Cara Perpajakan. 2007. Jakarta: Menteri Hukum dan Hak Asasi Manusia Republik Indonesia.

Undang-Undang Republik Indonesia Nomor 28 Tahun 2009 tentang Pajak Daerah dan Retribusi Daerah. 2011. Jakarta Selatan: Visi Media.

Undang-Undang Republik Indonesia Nomor 33 Tahun 2004 tentang Perimbangan Keuangan Antara Pemerintah Pusat dan Pemerintah Daerah.

Undang-Undang Republik Indonesia Nomor 36 Tahun 2008 dan Peraturan Pemerintah RI tentang Perpajakan. Bandung: Citra Umbara.

Waluyo. 2011. Perpajakan Indonesia Edisi 10 Buku 1. Jakarta: Salemba Empat.

Widyaningsih, A. 2009. Analisis Potensi Penerimaan Pajak Reklame Kota Bandung Periode Tahun 2001-2007. Jurnal Fokus Ekonomi. 